\title{
REACTIONS OF DIAZOMETHANE WITH SULFONYL-ACTIVATED DOUBLE BONDS
}

\author{
R. Helder, T. Doornbos, ${ }^{a}$ J. Strating and B. Zwanenburg ${ }^{b *}$ \\ Department of Organic Chemistry, The University, Zernikelaan, Groningen, The Netherlands
}

(Received in UK 4 December 1972; Accepted for publication 8 January 1973)

\begin{abstract}
The cyclo-addition reaction of diazomethane with $\alpha, \beta$-unsaturated sulfones is described. Divinyl sulfone and phenyl vinyl sulfone give 1- or 2-pyrazolines depending on the reaction conditions. cis- and trans-1,2-Bis(methylsulfonyl)ethene form pyrazolines, which on reaction with either triethylamine or excess of diazomethane lead to substituted pyrazoles.
\end{abstract}

The addition of diazomethane to double bonds activated by electron-withdrawing substituents such as carbonyl, nitro and nitrile is a well-documented route to substituted pyrazolines. ${ }^{1}$ However, the addition of diazomethane to $\alpha, \beta$-unsaturated sulfones is scarcely mentioned. Parham et $a l^{2}$ reported the formation of two types of pyrazolines from $\alpha, \beta$-unsaturated sulfones and diazomethane viz a normal addition product in which the $\mathrm{C}$ atom of the diazomethane is attached to the $\beta-C$ of the vinyl sulfone and an abnormal product with the diazocarbon attached to the $\alpha-\mathrm{C}$ of the unsaturated system. It is generally accepted $^{1}$ that the initial reaction products of diazomethane with activated double bonds are 1-pyrazolines, which however, may undergo a facile prototropic rearrangement to the corresponding 2-pyrazolines during crystallization, by gently warming or by a trace of acid or base. ${ }^{1 a}$ Backer et al. $^{3}$ reported that treatment of thiophene1,1-dioxides with excess of diazomethane gave rise to addition of diazomethane to only one double bond of the thiophene-1,1-dioxides.

We investigated the reaction of divinyl sulfone (1) - an open chain analogue of the thiophene-1,1dioxides - with diazomethane under similar conditions and we found that instead of one, both double bonds of 1 reacted smoothly.

Treatment of divinyl sulfone (1) with a basefree ethereal solution of diazomethane gave the 1-pyrazoline 2 as a mixture of the meso and $d l$ form in yields up to $90 \%$. In the presence of a trace of triethylamine the 2-pyrazoline 3 was obtained in $76 \%$ yield. Heating of 2 in acetonitrile in the presence of a little of triethylamine gave a quantitative rearrangement to 3 (Scheme 1).

aPresent address: Unilever Research Laboratory, Duiven, The Netherlands.

${ }^{b}$ Present address: Department of Organic Chemistry, University at Nijmegen, Toernooiveld, Nijmegen, The The Netherlands. To whom correspondence should be addressed.

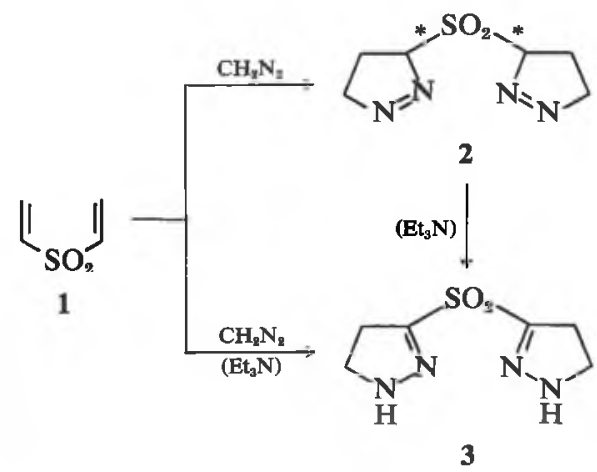

SCHEME 1

The structure of 3 was established by a correct elemental analysis, a NH absorption at 3340 $\mathrm{cm}^{-1}$ in the IR spectrum and an $A_{2} B_{2}$ pattern for the protons at $\mathrm{C}_{4}$ and $\mathrm{C}_{5}$ in the NMR spectrum. The structure of 2 (meso $+d l$ ) was evident from the elemental analysis, the NMR spectrum which showed four multiplets in the intensity ratio of $1: 1: 4: 4$ and the absence of a NH IR absorption. Careful crystallization of the reaction product 2 gave one of the isomers (either meso or $d l$ ) as a pure substance. Its NMR showed three multiplets in the intensity ratio of $1: 2: 2$. Heating of this pure isomer gave a quantitative tautomerization to bis-2-pyrazoline 3.

Parham et al. ${ }^{2}$ studied the addition of diazomethane to sulfones of the type $\mathrm{R}^{1}-\mathrm{SO}_{2}-\mathrm{CH}=$ CHR ${ }^{2}$. With $R^{2}$ being aryl, they found normal as well as abnormal addition products. With $\mathbf{R}^{2}$ being $\mathrm{H}$ or alkyl, only normal addition took place. The position of the double bond with respect to the substituent in the isolated 2-pyrazolines was not established. ${ }^{2}$ Since we were able to isolate a 1-pyrazoline from the (normal) addition reaction of diazomethane to 1 and since we could adjudge the position of the double bond in the corresponding 2-pyrazoline 3, we decided to reinvestigate one of Parham's sulfones. We found that the addition of diazomethane 
to phenyl vinyl sulfone produced a 1-pyrazoline (4). However, when the reaction was carried out in the presence of a trace of base, we isolated just as Parham et al. ${ }^{2}$ did, a 2-pyrazoline (5), erroneously denoted as 6 by these authors.<smiles>O=S(=O)(O)C1CCN=N1</smiles>

4<smiles>O=C(Oc1ccccc1)C1=NNCC1</smiles>

5

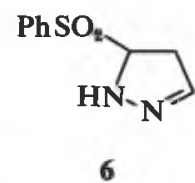

6
Having studied so far the addition of diazomethane to a double bond linked with one sulfonyl group (phenyl vinyl sulfone) and a sulfone connected with two double bonds (divinyl sulfone, 1) the series was completed by investigating the behaviour of a double bond flanked by two sulfonyl functions, e.g. cis-1,2-bis (methylsulfonyl)ethene (7)* (Scheme 2).

*When this work was carried out Meek and Fowler published their results on the reaction of diazomethane with cis-1,2-bis(p-tolylsulfonyl) ethene (compare 7). When the reaction was stopped as soon as the starting alkene was dissolved 3-p-tolylsulfonylpyrazole (compare 10) was isolated in $17 \%$ yield. Leaving overnight $\mathrm{cis}-1,2-$ bis ( $p$-tolylsulfonyl) ethene with excess of diazomethane resulted in a mixture from which 1-methyl-3(5)- $p$-tolylsulfonylpyrazole (compare 11 and 12) could be isolated in $57 \%$ yield. Product formation is rationalized by Meek and Fowler assuming sulfinate elimination from the intermediate 1-pyrazoline (compare 8). (J. S. Meek and J. S. Fowler, J. Org. Chem. 33, 985 (1968)).

†A good NMR spectrum of 9 could not be obtained; 9 was only sparingly soluble in chloroform and carbon tetrachloride, reacted with acetone and decomposed in polar solvents like dimethyl sulfoxide, water and trifluoroacetic acid.
The reaction of 7 with excess of diazomethane afforded two isomeric 1-methyl-methylsulfonylpyrazoles (m.p. $66 \cdot 5-67 \cdot 5^{\circ}, 67 \%$ and m.p. $77-78^{\circ}$, $18 \%$ ). The NMR spectra of these isomers differed only slightly (Experimental). The chemical shifts and coupling constants were compared with the literature data ${ }^{4}$ for the isomer identification of pyrazoles. On basis hereof the compound with m.p. $66 \cdot 5-67 \cdot 5^{\circ}$ was shown to be 1-methyl-5methylsulfonylpyrazole (11) and the isomer with m.p. $77-78^{\circ}$ to be 1-methyl-3-methylsulfonylpyrazole (12)-see Scheme 2. In order to gain more insight in the reaction of 7 with excess of diazomethane, it was treated with one equivalent of diazomethane. The added diazomethane solution was decolorized immediately and the adduct 9 precipitated nearly quantitatively and analytically pure. The IR† of 9 showed a NH absorption at $3370 \mathrm{~cm}^{-1}$ and was identical to the IR spectrum of the product obtained by treatment of trans-1,2bis(methylsulfonyl) ethene (13) with one equivalent of diazomethane. The reaction of 7 with one equivalent of diazomethane and one equivalent of triethylamine gave pyrazole 10 in $94 \%$ yield. The NMR spectrum of 10 showed two doublets for the ring protons, characteristic for 3-substituted pyrazoles.

The reaction sequence depicted in Scheme 2 is a likely explanation for the product formation from 7 in the presence of excess of diazomethane.

The alternative that sulfinic acid elimination from 8 takes place prior to the prototropic shift must be discarded because of the great ease by which the tautomerization to the 2-pyrazoline 9 takes place. Further evidence for the proposed mechanism is the nearly equal ratios of the quantities of 11 and 12 formed by the reaction of cis-1,2-bis(methylsulfonyl) ethene (7), trans-1,2-bis(methylsulfonyl)-

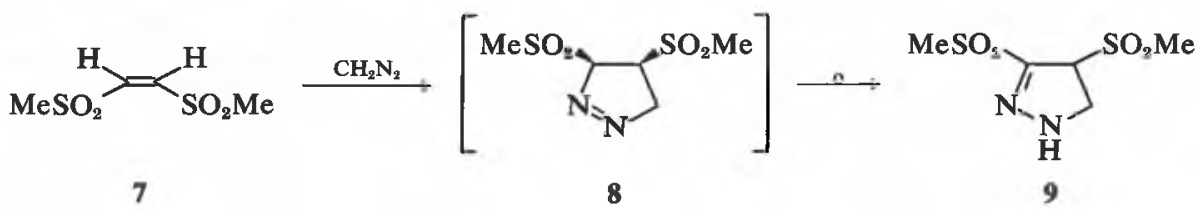

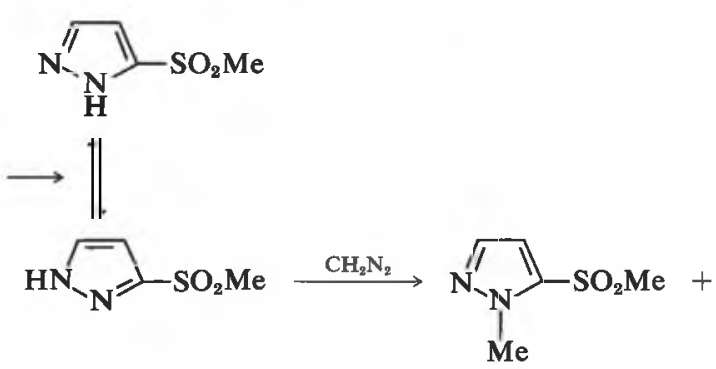

10
11

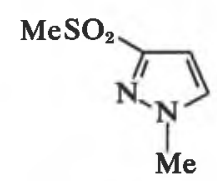

12 
ethene (13) and 3-methylsulfonylpyrazole (10) with diazomethane under identical conditions. As a third possibility can be envisaged $\mathbf{N}$-methylation of the 2-pyrazoline 9 with subsequent elimination of sulfinic acid. In that case one would expect only 1-methyl-3-methylsulfonylpyrazole (12). However, pyrazole 12 was isolated in a much lower yield than its isomer 11.

In strong contrast to the stability of pyrazoline 9 are unsuccessful attempts described recently by Witiak and Sinha ${ }^{5}$ to isolate or detect intermediate 1- or 2-pyrazolines in the reaction of cis-and trans$\beta$-chloroacrylates with diazomethane.

\section{EXPERIMENTAL}

M.ps are uncorrected. Microanalyses were performed by the analytical department of our laboratory under supervision of Mr. W. M. Hazenberg. NMR spectra were determined on a Varian A-60 spectrometer, using TMS as internal standard. IR spectra were taken on an Unicam SP 200.

Di(1-pyrazolin-3-yl)sulfone (2). To a soln of $820 \mathrm{mg}$ $(6.9 \mathrm{mmole})$ of 1 in $50 \mathrm{ml}$ ether was added at $0^{\circ} 24 \mathrm{ml}$ $1 \mathrm{M} \mathrm{CH} \mathrm{CH}_{2}$ in ether. Immediate decolorization of the first part of the $\mathrm{CH}_{2} \mathrm{~N}_{2}$ soln and formation of a white ppt indicated a fast reaction. After $18 \mathrm{hr}$ at $0^{\circ}, 2$ was filtered off and washed with ether, yield, $800 \mathrm{mg}$ (58\%). Two crystallizations from $\mathrm{CH}_{2} \mathrm{Cl}_{2}$-ether-pentane gave $600 \mathrm{mg}$ of an equimolar mixture of both diastereomers 2. NMR $\left(\mathrm{CDCl}_{3}\right): \delta 6.44\left(\mathrm{~m}, 1 \mathrm{H}\right.$ on $\left.\mathrm{C}_{3}\right), \delta 5.93(\mathrm{~m}, 1 \mathrm{H}$ on $\left.\mathrm{C}_{3}\right), \delta 4.80\left(\mathrm{~m}, 4 \mathrm{H}\right.$ on $\left.\mathrm{C}_{5}\right)$ and $\delta 2.13\left(\mathrm{~m}, 4 \mathrm{H}\right.$ on $\left.\mathrm{C}_{4}\right)$; IR: no NH absorption. (Found: C, 35.69; H, 5.00; N, 27.72; S, 15.87. Calc. for $\mathrm{C}_{6} \mathrm{H}_{10} \mathrm{~N}_{4} \mathrm{O}_{2} \mathrm{~S}: \mathrm{C}, 35 \cdot 63 ; \mathrm{H}$, $4.98 ; \mathrm{N}, 27.71 ; \mathrm{S}, 15.85 \%$ ). After 4 crystallizations one diastereomer 2 was obtained pure; NMR $\left(\mathrm{CDCl}_{3}\right): \delta$ $5.93\left(\mathrm{~m}, 1 \mathrm{H}\right.$ on $\left.\mathrm{C}_{3}\right), 84.80\left(\mathrm{~m}, 2 \mathrm{H}\right.$ on $\left.\mathrm{C}_{5}\right)$ and $\delta 2.13(\mathrm{~m}$, $2 \mathrm{H}$ on $\mathrm{C}_{4}$ ); IR: no $\mathrm{NH}$ absorption, m.p. 99-104 ${ }^{\circ}$ (dec). (Found: C, 35-43; H, 4-99; N, 27-79; S, 15.83\%). Analytically pure 2 (one diastereomer) heated for $15 \mathrm{~min}$ in $\mathrm{MeCN}$ in the presence of $\mathrm{Et}_{3} \mathrm{~N}$ gave a complete rearrangement to 3 as was evident from the NMR spectrum.

Di(2-pyrazolin-3-yl)sulfone (3). To a soln of $1773 \mathrm{mg}$ $\left(15.0\right.$ mmole) of 1 in $150 \mathrm{ml}$ ether was added at $0^{\circ} 60 \mathrm{ml}$ $1 \mathrm{M} \mathrm{CH}_{2} \mathrm{~N}_{2}$ in ether and $200 \mathrm{mg} \mathrm{NaOH}$. After $18 \mathrm{hr}$ at $-5^{\circ}$ the mixture was filtered giving $2300 \mathrm{mg}(76 \%)$ of 3. Two crystallizations from $\mathrm{CH}_{2} \mathrm{Cl}_{2}$-ether-pentane afforded analytically pure product, m.p. 101.5-103.5 (dec). (Found: C, 35.78; H, 5.14; N, 27.58; S, 15.88. Calc. for $\mathrm{C}_{6} \mathrm{H}_{10} \mathrm{~N}_{4} \mathrm{O}_{2} \mathrm{~S}: \mathrm{C}, 35 \cdot 63 ; \mathrm{H}, 4.98 ; \mathrm{N}, 27 \cdot 71 ; \mathrm{S}, 15 \cdot 85 \%$ ); NMR $\left(\mathrm{CDCl}_{3}\right) ; \delta 6.48(\mathrm{~s}, 0.8 \mathrm{H}, \mathrm{NH})$ and $\delta 3.40\left(\mathrm{~A}_{2} \mathrm{~B}_{2}\right.$ pattern, $2 \mathrm{H}$ on $\mathrm{C}_{4}$ and $2 \mathrm{H}$ on $\mathrm{C}_{5}$ ); IR: $3330 \mathrm{~cm}^{-1}$ (NH).

3-Phenylsulfonyl-1-pyrazoline (4). To $840 \mathrm{mg}$ ( $5 \mathrm{mmole}$ ) phenyl vinyl sulfone ${ }^{2}$ in $20 \mathrm{ml}$ dry ether was added at $0^{\circ}$ $35 \mathrm{ml} 0.4 \mathrm{M}$ ethereal $\mathrm{CH}_{2} \mathrm{~N}_{2}$. After $48 \mathrm{hr}$ at $-20^{\circ} 790 \mathrm{mg}$ (75\%) of 4 was filtered off. Two crystallizations from $\mathrm{CH}_{2} \mathrm{Cl}_{2}$-ether-pentane afforded analytically pure 4, m.p. 79-82 ${ }^{\circ}$ (dec). (Found: C, 51.15; H, 4.90; N, 13.06; $\mathrm{S}, 15 \cdot 20$. Calc. for $\mathrm{C}_{9} \mathrm{H}_{10} \mathrm{~N}_{2} \mathrm{O}_{2} \mathrm{~S}: \mathrm{C}, 51 \cdot 41 ; \mathrm{H}, 4 \cdot 79 ; \mathrm{N}$, 13.35; S, 15.25\%); NMR $\left(\mathrm{CDCl}_{3}\right): \delta 7.75(\mathrm{~m}, 5 \mathrm{H}), \delta$ $5.75\left(\mathrm{~m}, 1 \mathrm{H}\right.$ on $\left.\mathrm{C}_{3}\right), \delta 4.57\left(\mathrm{~m}, 2 \mathrm{H}\right.$ on $\left.\mathrm{C}_{5}\right)$ and $\delta 2.05$ (m, 2 H on $\mathrm{C}_{4}$ ); IR: no $\mathrm{NH}$ absorption.

3-Phenylsulfonyl-2-pyrazoline (5). To $840 \mathrm{mg}$ ( $5 \mathrm{mmole}$ ) phenyl vinyl sulfone ${ }^{2}$ in $20 \mathrm{ml}$ dry ether was added at $0^{\circ}$ $20 \mathrm{ml} \mathrm{0.4} \mathrm{M}$ ethereal $\mathrm{CH}_{2} \mathrm{~N}_{2}$ and $30 \mathrm{mg} \mathrm{Et}_{3} \mathrm{~N}$. After $48 \mathrm{hr}$ at $-20^{\circ} 885 \mathrm{mg}(85 \%)$ of 5 was isolated by filtration. After 3 crystallizations from EtOH-pentane 5 was obtained analytically pure, m.p. $95 \cdot 5-97^{\circ}$. (Found: C, $51 \cdot 44 ; \mathrm{H}, 4 \cdot 90 ; \mathrm{N}, 13 \cdot 04 ; \mathrm{S}, 15 \cdot 24$. Calc. for $\mathrm{C}_{9} \mathrm{H}_{10} \mathrm{~N}_{2} \mathrm{O}_{2} \mathrm{~S}$ : C, 51.41; H, 4.79; N, 13.33; S, 15.25\%); NMR $\left(\mathrm{CDCl}_{3}\right)$ : $\delta 7.75(\mathrm{~m}, 5 \mathrm{H}), \delta 6 \cdot 30($ broad $\mathrm{s}, \mathrm{NH})$ and $\delta 3.30\left(\mathrm{~A}_{2} \mathrm{~B}_{2}\right.$ pattern, $4 \mathrm{H})$; IR: $3380 \mathrm{~cm}^{-1}(\mathrm{NH})$.

Conversion of 4 into $5.420 \mathrm{mg}$ of 4 and $3 \mathrm{mg}$ of $\mathrm{Et}_{3} \mathrm{~N}$ in $50 \mathrm{ml}$ ether were kept at $5^{\circ}$ for $48 \mathrm{hr}$. After cooling to $-20^{\circ}$ filtration of the mixture gave $320 \mathrm{mg}$ of 5 identified by IR (NH absorption at $3380 \mathrm{~cm}^{-1}$ ) and m.p. (94-97 ).

1-Methyl-5-methylsulfonylpyrazole (11) and 1-methyl-3methylsulfonylpyrazole (12). To $920 \mathrm{mg}$ ( $5 \mathrm{mmole}$ ) of 7 in $10 \mathrm{ml} \mathrm{CH}_{2} \mathrm{Cl}_{2}$ and $30 \mathrm{ml}$ dioxane was added $100 \mathrm{ml}$ $0.5 \mathrm{M}$ ethereal $\mathrm{CH}_{2} \mathrm{~N}_{2}$. After standing for 1 week at $5^{\circ}$ the $\mathrm{CH}_{2} \mathrm{~N}_{2}$ had disappeared. Solvents were removed under diminished pressure. The resulting oil was chromatographed over $\mathrm{Al}_{2} \mathrm{O}_{3}$ (activity II-III, neutral, benzeneether), yield, $540 \mathrm{mg}(67 \%)$ of 11 , and $147 \mathrm{mg}(18 \%)$ of 12. Pyrazole 11 was obtained analytically pure by 2 crystallizations from ether, m.p. $66 \cdot 5-67 \cdot 5^{\circ}$ (Found: $C$, 37.93; H, 5.08; N, 17.44; S, 20.13. Calc. for $\mathrm{C}_{5} \mathrm{H}_{8} \mathrm{~N}_{2} \mathrm{O}_{2} \mathrm{~S}$ : C, 37.48; $\mathrm{H}, 5 \cdot 03 ; \mathrm{N}, 17 \cdot 49 ; \mathrm{S}, 20 \cdot 02 \%)$; NMR $\left(\mathrm{CDCl}_{3}\right)$ : $\delta 7.51$ (d, $1 \mathrm{H}, \mathrm{J} 2 \mathrm{c} / \mathrm{s}), \delta 6.85 \mathrm{~d}, 1 \mathrm{H}, \mathrm{J} 2 \mathrm{c} / \mathrm{s}), 84.16(\mathrm{~s}$, $3 \mathrm{H}, \mathrm{N}-\mathrm{Me}$ ) and $\delta 3 \cdot 17\left(\mathrm{~s}, 3 \mathrm{H}, \mathrm{SO}_{2}-\mathrm{Me}\right.$ ); IR: no $\mathrm{NH}$ absorption. Compound 12 was also obtained analytically pure by 2 crystallizations from ether, m.p. $77-78^{\circ}$. (Found: C, 37.34; $\mathrm{H}, 4.86 ; \mathrm{N}, 17.57$; S, 20.22\%); NMR $\left(\mathrm{CDCl}_{3}\right)$; $\delta 7.48(\mathrm{~d}, 1 \mathrm{H}, \mathrm{J} 2.5 \mathrm{c} / \mathrm{s}), \delta 6.75(\mathrm{~d}, 1 \mathrm{H}, \mathrm{J} 2.5 \mathrm{c} / \mathrm{s}), 84.00$ (s, $3 \mathrm{H}, \mathrm{N}-\mathrm{Me}$ ) and $\delta 3.17$ (s, $3 \mathrm{H}, \mathrm{SO}_{2}-\mathrm{Me}$ ); IR: no NH absorption.

3,4-Di(methylsulfonyl)-2-pyrazoline (9). To $736 \mathrm{mg}$ (4 mmole) of 7 in $20 \mathrm{ml} \mathrm{CH}_{2} \mathrm{Cl}_{2}$ and $20 \mathrm{ml}$ ether was added at $0^{\circ} 8 \mathrm{ml} 0.5 \mathrm{M} \mathrm{CH}_{2} \mathrm{~N}_{2}$ in ether. After cooling to $-20^{\circ} 810 \mathrm{mg}(90 \%)$ of 9 could be filtered off. Washing with $\mathrm{CH}_{2} \mathrm{Cl}_{2}$, ether and pentane gave analytically pure 9, m.p. $130-133^{\circ}$ (dec). (Found: C, 26.50; H, 4.45; N, 12.27; S, 28.06. Calc. for $\mathrm{C}_{5} \mathrm{H}_{10} \mathrm{~N}_{2} \mathrm{O}_{4} \mathrm{~S}_{2}: \mathrm{C}, 26.54 ; \mathrm{H}, 4.45 ; \mathrm{N}$, 12.38; S, 28.35\%). The IR showed a NH absorption $\left(3370 \mathrm{~cm}^{-1}\right)$. An attempt to obtain 9 analytically pure by crystallization from acetone $(5 \mathrm{x})$ failed since 9 reacted with acetone. The elemental analysis of the new product (m.p. 131.5-135 ${ }^{\circ}, \mathrm{dec}$ ), was in agreement with a structure of a compound formed by condensation of 2 mole of 9 with 1 mole of acetone. (Found: $\mathrm{C}, 32.15 ; \mathrm{H}, 4.98 ; \mathrm{N}$, 11.29; S, 25.52. Calc. for $\mathrm{C}_{13} \mathrm{H}_{24} \mathrm{~N}_{4} \mathrm{O}_{8} \mathrm{~S}_{4}: \mathrm{C}, 31 \cdot 70 ; \mathrm{H}$, $4 \cdot 91$; N, 11.37; S, 26.04\%); IR: no NH absorption.

3-Methylsulfonylpyrazole (10). To $920 \mathrm{mg}(5 \mathrm{mmole})$ of 7 in $10 \mathrm{ml}$ dioxane was added at $0^{\circ} 10 \mathrm{ml} \mathrm{0.5} \mathrm{M} \mathrm{CH}_{2} \mathrm{~N}_{2}$ in ether and $600 \mathrm{mg} \mathrm{Et} \mathrm{H}_{3} \mathrm{~N}$. After standing for $48 \mathrm{hr}$ at $5^{\circ}$ the solvents were evaporated under diminished pressure. The resulting oil was chromatographed (silica gel, EtOAc) giving $685 \mathrm{mg}(94 \%)$ of 10 . Two crystallizations from EtOH gave analytically pure product, m.p. 99-103. Found: C, 32.84; H, 4.15; N, 19.36; S, 22.08. Calc. for $\mathrm{C}_{4} \mathrm{H}_{6} \mathrm{~N}_{2} \mathrm{O}_{2} \mathrm{~S}: \mathrm{C}, 32.86 ; \mathrm{H}, 4 \cdot 14 ; \mathrm{N}, 19 \cdot 17 ; \mathrm{S}, 21.94 \%$ ); NMR $\left(\mathrm{CDCl}_{3}\right): \delta 7.90(\mathrm{~d}, 1 \mathrm{H}, \mathrm{J} 2.5 \mathrm{c} / \mathrm{s}), \delta 6.83(\mathrm{~d}, 1 \mathrm{H}$, $\mathrm{J} 2 \cdot 5 \mathrm{c} / \mathrm{s})$ and $\delta 3 \cdot 15(\mathrm{~s}, 3 \mathrm{H}) ; \operatorname{IR} 3340 \mathrm{~cm}^{-1}(\mathrm{NH})$.

The reaction of cis-resp. trans-1,2-bis(methylsulfonyl)ethene and 10 with $\mathrm{CH}_{2} \mathrm{~N}_{2}$ under identical conditions. To $92 \mathrm{mg}$ of 7 in $5 \mathrm{ml} \mathrm{CH}_{2} \mathrm{Cl}_{2}$ was added at $0^{\circ} 15 \mathrm{ml}$ of 0.45 $\mathrm{M} \mathrm{CH} \mathrm{C}_{2}$ in ether. After standing for 1 week at $5^{\circ}$ volatile components were removed on a vacuum evaporator, giving a nearly colourless oil. The NMR spectrum showed 11 and 12 to be present in the ratio of $3.4: 1$, and in addition some minor impurities. The same procedure was applied to 13 . The ratio of 11 and 12 was found to be 
4-7: 1 . When $35 \mathrm{mg}$ of 10 in $5 \mathrm{ml} \mathrm{CH}_{2} \mathrm{Cl}_{2}$ was treated with $15 \mathrm{ml} 0.45 \mathrm{M} \mathrm{CH}_{2} \mathrm{~N}_{2}$ the ratio of 11 and 12 amounted to 4.5:1.

\section{REFERENCES}

${ }^{10}$ Houben-Weyl, Methoden der organischen Chemie (Vierte Auflage) Stickstoffverbindungen I, Teil 4, p. 804 e.f. (1968);

${ }^{b}$ The Chemistry of Heterocyclic Compounds. (Edited by A. Weissberger), Interscience (1967) Vol 22: L. C.
Behr, R. Fusco, C. H. Jarboe, Pyrazoles, Pyrazolines, Pyrazolidines, Indazoles and Condensed Rings (Edited by R. H. Wiley).

${ }^{2}$ W. E. Parham, F. D. Blake and D. R. Theissen, J. Org. Chem. 27, 2415 (1962)

${ }^{3}$ H. J. Backer, N. Dost and J. Knotnerus, Rec. Trav. Chim. 68, 237 (1949)

${ }^{4}$ L. G. Tensmeyer and C. Ainsworth, J. Org. Chem. 31, 1878 (1966)

${ }^{5}$ D. T. Witiak and B. K. Sinha, Ibid. 35, 501 (1970) 